\title{
INTER-WAR RIGHT-WING MOVEMENTS IN THE BALTIC STATES AND THEIR RELIGIOUS AFFILIATION
}

\author{
Agita MisĀNE \\ Academic Centre for the Study of Religion \\ Institute of Philosophy and Sociology, University of Latvia \\ 1. Akademijas laukums, LV 1940 Riga, Latvia
}

\begin{abstract}
The article discusses the different religious affiliations of three inter-war right-wing movements in the Baltic States. The Lithuanian Iron Wolf remained indifferent to the religious issues, the Estonian Veterans' League stressed the value of the Christian faith and formed links with the Lutheran Church, while the Latvian Thundercross favoured the ideas of the pre-Christian revivalism and closely collaborated with the Dievturi movement. The difference in religious choice is explained by (1) the different character of the Estonian (radical right) and the Latvian (extreme right) movements and (2) the formalisation of the pre-Christian revivalism ideology according to the Protestant pattern. Although the doctrine differed greatly, the style of thought and manner of presentation made the Latvian pre-Christian revivalism more open to the right-wing political thought - a feature commonly found with the Protestant Churches of Europe.

Keywords: religion, nationalism, pre-Christian revivalism, radical politics, Neo-Paganism, Protestantism, Dievturība, "The Iron Wolf", "Thundercross", "Estonian Veterans' League”
\end{abstract}

Foreigners usually see the Baltic States as a unitary space. This is probably due both to their geographical location and their shared historical experience. Lithuania, Latvia and Estonia emerged as parliamentary republics at the end of the First World War in place of the Western provinces of the Russian Empire. Later on, authoritarian regimes of Antanas Smetona (1926-40), Kārlis Ulmanis (1934-40) and Konstantin Päts (1934-40) were imposed on Lithuania, Latvia and Estonia, respectively. All three Baltic States were occupied by Soviet troops in 1940 and by Nazi Germany in 1941-45, and were re-incorporated into the Soviet Union. The Baltic States regained independence in 1991.

The religious histories of the Baltic peoples were, however, rather disparate. Lithuania was and still remains, a Roman Catholic country with close, though not formally recognised, ties between the Church and the state. It is undoubtedly the least secularised of all Baltic States. In contrast, Estonia today is a secular country where the largest religious organisation is the Estonian Evangelic Lutheran Church. By the 1934 Census, $78 \%$ of the entire population were Lutheran and 19\% Orthodox. ${ }^{1}$ The Latvian case is probably the most complex. At present, the Roman Catholic and Lutheran Churches have - at least nominally - about the same numbers of the adherents and there is also a considerable Russian Orthodox population. Ac-

${ }^{1}$ RAUN 1991: 135. 
cording to the 1935 Census, $55.2 \%$ of the 1950502 population were Lutheran, 24.4\% Roman Catholic, 8.9\% Orthodox; other denominations were represented by smaller numbers. ${ }^{2}$

This chapter will analyse one particular aspect of Baltic religious history, namely, the religious affiliations of right-wing movements. I would not agree that "movements focused on the direct political action do tend to compete with religious movements, especially sects, for adherents. People who find satisfaction in religious compensators tend not to be moved to embrace political movement [...] people tend to support either one or another, not both." 3 Though some political ideologies possess certain facets of religion and are sometimes viewed as religions in themselves - Fascism and Nazism, for example - yet the links between political and religious organisations deserve to be explored in detail.

Specifically, I will focus on the relationship between the Latvian extreme right and pre-Christian revivalism. The appeal of the latter to right wing politicians is well known. Such ideas as of the "spirit of the nation and/or race" and military valour often evoked by the right together with the racial and cultural exclusiveness and supremacy fit perfectly with the commonly held - and mostly incorrect - vision of the early European religions with their pantheons of austere warrior gods. The symbolism of festivals and of signs like swastika had proved equally attractive.

Although the relationship between particular Christian Churches and the Right has been at times ambiguous, as far as doctrine is concerned, Christianity is a problem for the right-wing political thought. One reason is the strong awareness of the weakness of the human nature that the majority of the Christian Churches share - a very different anthropological perspective from the emphasis on youth, health and masculinity, carried in its extreme to ruthlessness, found within the right ideology. Another reason is the fact that the Christian doctrine raises the human being - in terms of axiology - above environment, both nature and social and/or national group. Man is first and foremost valued as an individual and not as a member of a particular nation or social class. According to the Christian doctrine, a person is also individually and not collectively answerable to God. Ideology of the radical and extreme right movements, in contrast, called for subordination of the individual needs and values to the needs of the nation. The established Churches were often seen as ideological rivals challenging the authority of the political elite. It is not surprising then, for example, that Nazi state officials either sought to build the bridge between the German Evangelic Church and National Socialism by modifying Christian doctrine and supporting the so called German Christianity, or called for the abandonment of Christianity entirely - as Alfred Rosenberg did. ${ }^{4}$ Recently, concerns have been expressed as to links between the Neo-Pagan thought and the extreme rightwing movements in Russia. ${ }^{5}$ V. YEMELIANOV, one of the founders of the ill-famed

2 KRUMINA-KONKOVA-GILLS 1998: 430.

${ }^{3}$ STARK-BAINBRIDGE 1985: 524.

${ }^{4}$ See CeCIL 1972.

${ }^{5}$ See SHNIRELMAN 1998a. 
Russian nationalist organisation Pamyat recalled that Pamyat was originally intended to be an anti-Christian movement with strong neo-pagan emphasis. ${ }^{6}$ Pamyat changed its religious orientation to Orthodox in the late eighties - presumably understanding that this would secure a wider mass support.

At this point it is appropriate to say something about the terminology. The present day Neo-Pagans who aspire to reinstate the religions of Celtic Britain, Germany or the Classical Antiquity are, in the words of STARK and BAINBRIDGE, "cousins of the magic and witchcraft family". ${ }^{7}$ The modern Neo-Paganism, which originated in the sixties - the Wiccans, Great Goddess worshippers and the like - in all its diversity is generally oriented towards nature and sometimes also the occult. ${ }^{8}$ Therefore the word "Pagan" i.e. nature-worshipper, seems to be appropriate. In the majority of cases, it is how adherents identify themselves. Margot ADLER's survey showed that $96.4 \%$ of the respondents during her research on Neo-Paganism considered themselves "Pagans" and "most agreed that Pagans were members of pantheistic, tribal, shamanistic nature religions and that modern Neo-Paganism embodied a respect for the earth and the nature's laws and a conception of deity as immanent". ${ }^{9}$ The Pagan education Network web page defines their religion as follows:

Paganism is a broad, eclectic contemporary religious movement that encompasses shamanistic, ecstatic, polytheistic, and magical religions. Most of the religions termed Pagan are characterised by nature-centred spirituality, honouring of pre-Christian deities, dynamic, personal belief systems, lack of institualization, a quest to develop the self, and acceptance and encouragement of diversity. Paganism is sometimes referred to as Neo-Paganism to emphasise its connections to as well as difference from pre-Christian Religions. ${ }^{10}$

Thus the Western Neo-Paganism today could be seen in line with the New Age as part of a wider syncretic movement which promotes religious subculture with particular references to feminism, environmental protection, body awareness ("feel

6 Yemelianov in Russkaia Pravda Nr. 3, 1994, quoted in SHNiRELMan 1998b: 6.

${ }^{7}$ STARK-BAINBRIDGE 1985: 199.

${ }^{8}$ Yet, it is interesting that the gathering originally announced as the World Congress of Pagan Religions and held in Vilnius, Lithuania, from 20 to 24 June 1998, changed its name to World Congress of Ethnic Religions. The declaration released by the delegates promoted religious diversity and emphasised both environmental and ethnic aspects. It said: All cultures and all native religions and faiths should be equally valued and respected. Each region and each people have their distinctive local traditions (native faith, world outlook, mythology, folklore etc.) which articulate their love of their land and history, and cultivate a regard of sacredness of all life and divinity of Nature. We believe that the dawn of a new era of individual and intellectual freedom and global exchange of views and information gives us an opportunity to start again to return to our own native spiritual roots in order to re-claim our religious heritage. We are worshippers of Nature just as whole mankind was, for the last $96 \%$ of its history.

${ }^{9}$ ADLER 1985: 459.

${ }^{10} \mathrm{http} / / /$ www.bloomington.in.us/ pen/mpagan.html. As on 29.02.00. 
good" religion), alternative healing, benevolent ("white") magic and the like. They may have links with the Green movement, but are otherwise politically passive.

Inter-war pre-Christian revivalism was a very different religious phenomenon. Neither adherents in Germany, nor the groups in the Baltic States, who tried to revive what they considered to be the authentic religions of their nations, considered themselves Pagans. The basis for the reanimation of the lost gods was usually found in either mythological texts or medieval chronicles or - as in the Latvian case - in folklore. The ethnic (sometimes racial) and cultural aspects were emphasised, but nature was an issue of considerably less, if any, importance. Present day Neo-Pagans are usually at ease with the fact that the rituals they practice are of their own creation. In the case of the inter-war period revivalists we are dealing with so called "invented tradition" - seemingly ancient, but in reality recent, deliberately constructed and formally introduced procedures and ethnic markers appearing within a brief period of time and conditioned, in E. HOBSBAWM's words, "to inculcate certain values and norms of behaviour by repetition, which automatically implies continuity with the past." 11 Hence, for the purpose of the present analysis I will use the term "pre-Christian revivalism" as preferable to "Neo-Paganism".

The right-wing movements that were politically active in the Baltic States during the inter-war period were related in terms of their nationalist zeal and criticism of the weaknesses of the parliamentary democracy. Before the authoritarian regimes were imposed in their respective countries they attacked the corruptive nature of the political parties and promoted the idea of an integrated nation-state under the leadership of a directly-elected president; afterwards, they attacked the leaders of their countries for being too moderate, i.e. "soft" on what they saw as enemies of their nations. Although the Baltic right had their vision of the economic development of their countries, they still did not focus on economic policy.

The Lithuanian political organisation which would qualify as a right-wing movement, Geležinis Vilkas (the Iron Wolf) was initiated in 1927 by the authoritarian government which had in its turn been formed after a coup d'état in the previous year. Formally, the Lithuanian president Smetona was its chief while the real control was in the hands of the prime minister Augustinas Voldemaras. The organisation was officially registered as a sports club, while the government's intention had been to develop it into a national guard. Gelezinis Vilkas never had a mass following and remained somewhat clandestine until it was reorganised into the Lithuanian Nationalists' party (Lietuviu Nacionalistu Partija) while some of its membership remained loyal to Voldemaras (dismissed in 1929) and continued its activities illegally and on limited scale. For the purpose of this analysis it is noteworthy that neither the "Wolves" nor their successors had religious values or experiences high on their priority lists. The Lithuanian Nationalists' Party supported the separation of church and state, while nonetheless regarding "religion as a virtue". ${ }^{12}$ To the best of my knowl-

${ }^{11}$ Hobsbawm 1983: 1.

12 MisiunAS 1970: 102. 
edge, the members of Geležinis Vilkas remained indifferent to the ideas of the preChristian revivalists. ${ }^{13}$

As the name itself suggests, Eesti Vabadussõjalaste Liit ${ }^{14}$ (the Estonian War of Independence Veteran's League, hereafter EVL) was founded by veterans of the Estonian War of Independence (1918-20). The organisation appeared under the name Eesti Vabadussõljalaste Keskliit (The Estonian War of Independence Veterans' Central League) in 1929 and changed the name to its shorter version in 1933.

Originally only individuals who had taken part in the War of Independence were accepted to full membership but after 1932 the membership was opened up to those sharing the ideas of the movement and the "spirit of the War of Independence". The movement became a political party later the same year. The Veterans attempted several constitutional amendments by means of initiating referendums. The above mentioned "spirit of the War of Independence" was the bedrock of EVL's ideology, meaning "patriotism, honesty and readiness to suffer". ${ }^{15}$ One may say that EVL followed an idea of collective salvation through political activity - the process that had started by the Veterans' shared sacrifice at the battlefield.

Although EVL had no formal connection to any of the Christian Churches in the country, the Veterans often used Christian rhetoric and associated themselves with the ethic values represented by the teaching of the Christian Church. ${ }^{16}$ League's newspaper Võitlus (Struggle) stressed that "our new Estonia must tie itself to the church and provide it with the widest opportunity to disseminate Christ's Gospel". ${ }^{17}$ The Veterans started their meetings with a prayer led by a Lutheran and/or Orthodox priest in commemoration of their fallen comrades. Generally EVL contrasted themselves favourably with the secularism and materialism of other political parties. The latter, in their turn, accused EVL of entering into some kind of conspiracy with the aim of according broader privileges to the Lutheran Church. This was repeatedly disclaimed by EVL.

Like in case of their Lithuanian counterparts, the Veterans' ideology bore no reference to the activities of the Estonian pre-Christian revivalists, the movement identifying itself as Taara usk (Taara creed). The latter originated in 1925 and proposed the worship of Old Estonian thunder-god Taara ${ }^{18}$ with an aim of laying some

\footnotetext{
${ }^{13}$ The Lithuanian pre-Christian revivalism, the "Romuva Belief" was inspired by the works of the writer and philosopher Vydūnas but was still a marginal phenomenon during the inter-war period. The movement, revitalised in 1967, is presently much stronger. See more on it in: RAMOŠKAITESVERDIOLIENE 1996.

${ }^{14}$ The most detailed study of the movement currently available is the doctoral dissertation of Estonian historian Andres KASEKAMP (KASEKAMP 1996). I am also grateful to him for information and discussions on various aspects of EVL.

15 Võitlus on 22 April, 1933, quoted in KASEKAMP 1996.

${ }^{16}$ See KASEKAMP 1996: 116-118.

17 Võitlus on 1 August, 1933, quoted in KASEKAMP 1996: 117.

18 "Taara, avita!" (Taara, help!) is a phrase once mentioned in the Henricus Chronicle Livonicum, a medieval chronicle devoted to the events in Livonia (Northeast Latvia) and Estonia. There is no other reference to such a deity in the Estonian sources.
} 
kind of new foundation to the support of the Estonian statehood..$^{19}$ It is interesting that Kustus Utuste, one of the leaders of the movement, was actually a military man and a veteran of the War of Independence. However, he never joined EVL.

Remarkably, the ties between the Lutheran Church and the radical right in Finland were even stronger. The Lapua movement (1929-32) and its successor, Isänmaalinen kansanliike (Patriotic People's Movement) even described their activities as religious crusades. This has been attributed to the impact of the Pietist tradition in Ostrobothnia, the area where the Lapua movement had originated. ${ }^{20}$

The Latvian movement that bore certain similarities to EVL, Pèrkonkrusts (Thundercross), emerged in 1932, originally under the name Ugunskrusts (Fire cross). ${ }^{21}$ When the Prime Minister Ulmanis declared the state of siege on 15 May 1934, all political parties were banned following the dissolution of the Parliament. From then on, Perrkonkrusts was one of the few political organisations that continued their activities illegally. In fact, the members of Perrkonkrusts had been on and off the legal political scene for all the time of its existence. ${ }^{22}$ The organisation was founded by the former members of several political movements, mostly Latvju Nacionālais Klubs (the Latvian National Club), that had been active during the twenties and then banned as paramilitary organisations threatening the public order. Ugunskrusts was banned by the Riga Regional Court in a year after its appearance and had to reemerge under a different name. Not surprising then, that compared to their Estonian counterparts Pérkonkrusts members were to a lesser degree involved in legal political activity, like initiating constitutional changes or standing for the parliament elections. The organisation described its chief goal as "Latvia for the Latvians" and proposed their political principles as follows:

1. Supreme power in Latvia belongs to the Latvian people.

2. The good of the nation is of higher value than individual freedom.

3. The premise of the state economy is the inner colonisation of the nations resources.

4. A state president elected by the people for five years, a parliament for the representation of commerce, a government subordinate to the president. ${ }^{23}$

The driving personality and the chief spokesperson of the organisation was Gustavs Celmiņš, a young civil servant. One of the movement's peculiarities was its

\footnotetext{
19 See VÄSTRIK 1996: 99.

${ }^{20}$ See KASEKAMP 1999: 593.

21 Both are Latvian names for swastika.

22 See PAEGLIS 1994.

23 G. CELMIN̦Š's speech of 17.09.33, published in Pérkonkrusts on 24.09.33, here quoted from GRIFFIN 1995: 217.
} 
strong animosity towards ethnic minorities, ${ }^{24}$ particularly the Baltic Germans and Jews. The Germans were a former dominant minority in Latvia and still retained a considerable social and economic influence, as well as an impact on the intellectual and cultural life. Jews were often found in medical and legal professions, arts, and also in trade. All problems in the country were thus blamed on minorities. Perkonkrusts rejected the civil definition of the Latvian nation and insisted on granting all political rights solely to the ethnic Latvians, Lithuanians and Estonians living in the country.

Another feature of Perkonkrusts was its close links with the pre-Christian revivalists in Latvia. The name "Thundercross" itself was reportedly coined by Ernests BRASTIŅŠ, ${ }^{25}$ one of the key figures in the history of Latvian nationalism. BRASTIŅŠ was also the founder and leader of the Dievturi ("those who keep the God"), a preChristian revivalist movement in Latvia. It emerged as a religious community in 1926 and originated, in BRASTIŅŠ's words, in response to the growing discontent of the Latvian intelligentsia with Christianity, secularisation and the spread of Marxist ideas. ${ }^{26}$ BRASTIŅš aimed to reconstruct what he considered to be the Old Latvian religion and introduce it as the official religion of the Latvian state. Christianity was, in his opinion, a religion created by Jews and forcibly imposed on Latvians by Germans. Therefore he considered it alien to the Latvian soul. BRASTIŅŠ was not treading on entirely new grounds. An earlier attempt to revitalise the religion lost through the centuries of forced Christianisation was made by Juris Lecis, a teacher who had tried to organise a non-Christian congregation in Jelgava during the World War I and also published a couple of pamphlets on the Old Latvian religion. His efforts received little public response. The social situation was not favourable as Latvia had not yet gained independence and the personal qualities of Lecis were not of a charismatic leader. Ernests BRASTIN̦Š (1892-1942), in contrast, possessed those gifts in abundance. He was an artist and a military man by training, educated at the Stiglitz School of Design and Emperor Paul's Military College, both in St. Petersburg. BRASTINSŠ served briefly in the Russian army before the October Revolution of 1917 and joined the Latvian regiments during the War of Independence (1918-20). After the war BRASTIŅŠ got involved in numerous projects. He was employed by the Board of Monuments (an organisation in charge of the preservation of the national heritage) and put all then known Latvian castle-mounds on the map - BRASTIN̦Š was an amateur archaeologist. He was granted a scholarship from the Latvian Folklore

\footnotetext{
${ }^{24}$ According to the Perkonkrusts ideologues, the ideal Latvian state would have no minorities at all. Remarkably, Thundercross did not consider the Estonians and Lithuanians minorities and generally supported the idea of Baltic unity.

${ }^{25}$ It is not entirely clear whether BRASTIN̦Š was himself a member of Pérkonkrusts. According to A. ŠILDE, an expatriate Latvian historian who had himself been a member of the organisation, he was. (ŠILDE 1988). When interrogated by the KGB in 1941, he denied his membership in Perkonkrusts and stated that his only connection was two lectures on the origins of the Latvian nation and religions he had delivered to the members of the organisation (see PELKAUS 1992: 26). In this BRASTIŅŠ was obviously and for understandable reasons - not telling the truth.

${ }^{26}$ BRASTIN̦Š 1936: 13.
} 
Archives to prepare an index of the mythological names in the Latvian folk songs. BRASTIŅŠ painted pictures, published books and articles on fine arts and ethnography, and tried to introduce a new style in painting, which he called "instinctivism". He was briefly the director of the War Museum in Riga. And above all, he was a keen polemist when it came to the national issues. He was also known for his love affairs and uninhibited temper and tolerated no alternative opinion. BRASTIŅš's picturesque personality has been portrayed in several Latvian novels.

Although formally recognised by the Ministry of Justice as a religious organisation, the Dievturi communion was still lacking doctrine and rituals in 1926. BRASTIN̦Š was a man of little religious education but he grasped intuitively the necessary features of the religion he was trying to formalise. In about five years time he provided the holy scriptures, the doctrine and the liturgy of the Dievturība. BRASTIN̦Š published a three-volume selection of Latvian folk-songs - Latvju Dievadziesmas (1928), Latvju tikumu dziesmas (1929) and Latvju gadskārtas dziesmas (1929). Sometimes ironically called "The Dievturi Bible", they contained songs about gods, virtues and seasonal rites. The Dievturi catechism, modelled on the Small Catechism of Martin Luther, came out in $1932 .{ }^{27}$ The Dievturi doctrine was highly syncretic ${ }^{28}$ and at times self-contradictory. It, or rather, he - as BRASTIN̦Š was the only creator of the doctrine, combined ardent denial of the Christian creed and various borrowings from it. BRASTIŅŠ proposed the veneration of three deities - Dievs (God), Māra (a female counterpart of God, in folklore - the Latvian name of St Mary) and Laima (the goddess of destiny), whom he interpreted as three persons of the same Ultimate Reality. He strongly objected to the concept of sin and, subsequently, to the notions of atonement and salvation. In BRASTIN̦Š's understanding, the Latvians were virtuous simply because they were Latvians and his goal of the "Latvianised Latvia" - a concept very close to Perkonkrusts "Latvia for Latvians" - was therefore seen as the fulfilment of the sacred mission of the Dievturi community. He repeatedly emphasised that the Nation is of higher value than the God or individual. A great part of the Dievturi writings described the glorious pre-Christian past and discussed the Indo-European ancestry of the Latvians. BRASTINSŠ views could also be described as the "flight from history" ${ }^{29}$ Although he was fully cognisant that the new religion is his own brainchild, he at the same time considered the Latvian culture and religion to remain unchanged through the centuries of the German and Russian rule. This assumption was used to support the view of the Dievturiba as the only and true IndoEuropean religion. All Europe, BRASTIŅŠ claimed, had for centuries waited for its recovery.

The political programme of the Dievturi (and probably BRASTIN̦Š's personal political aspirations, too) was revealed by BRASTIŅš as follows:

\footnotetext{
27 BRASTIŅŠ 1932.

28 See BEITNERE 1995

${ }^{29}$ See MisĀNE-PRIEDİTE 1997: 162-3 and PRIEDĪTE 1999: 242-3.
} 
Hence, our people's virtues could become the basis for healthy national policy. Any policy, understandably, presupposes that form of statehood, which could fulfil its ethical ideals most successfully. It is immediately evident that democracy in its present form does not appeal to the dievturi. Under democracy many presently rule who do not know how to rule, are incompetent to rule and do not desire to rule. Those rule to whom noble ideas are alien and who care only for their own welfare. It is clear that in a democratic society where decisions are taken after a secret vote of the majority, the laws and regulations would always be placed beneath the ultimate good and desideratum. Therefore only the virtuous, godly individual should be given power in the state, one who knows, is able and competent to lead the Latvian people towards the higher divine ideals. The form of statehood where the supreme temporal as well as spiritual power is concentrated in the hands of the same person is called theocracy. The national state shaped by the ideology of Dievturiba can be none other than theocratic. The bad and the imperfect will have to surrender to the good and the righteous. ${ }^{30}$

The Dievturi rituals were plain. The community gathered regularly on Sunday mornings for the "praise meeting", called "daudzinäjums" in Latvian. They sang folksongs and listened to kokle (a Latvian traditional musical instrument, similar to Finnish kantele). Speeches, addressing various doctrinal aspects and/or current issues, were also delivered. The Dievturi also met for outdoor seasonal festivities, like Midsummer Eve and other solstice celebrations. Particular rites of passage were introduced for child-births, weddings and funerals.

The Dievturi and Perrkonkrusts thus shared similar values and approaches to social issues. A number of individuals were members of both organisations and, according to the files of the Latvian Political Police, ${ }^{31}$ after 1934 the Dievturi also provided cover for Pèrkonkrusts meetings. In 1936, BRASTIŅš denoted an impressive sum of 1000 Lats - hardly possible to be his personal savings - to Pèrkonkrusts. The police undercover had also witnessed Pèrkonkrusts' members having meetings behind closed doors at the venue where Dievturi religious services were meanwhile held. ${ }^{32}$

The question to ask at this point is: why the religious affiliations of the Estonian and Latvian right were so different? Part of the explanation might be found if we comprehend that those were different types of the right-wing movements. Although EVL and Perkonkrusts are both usually branded as the radical right, ${ }^{33}$ I would argue

30 BRASTIN̦Š 1929: 11

31 The Latvian political police had both Dievturi and Pérkonkrusts under observation after 1934 and their archive (which was most likely the source of information when the KGB seized their files in 1940) holds enough evidence as to the links of both organisations (Latvian State Historical Archive 32352/5868).

32 Ibid.

33 KASEKAMP 1998. 
for qualifying Pérkonkrusts as the extreme rather than radical right. Roger EATWELL who has analysed the styles of thought of the right describes five different types - the reactionary right, the moderate right, the radical right, the extreme right, and the new right. ${ }^{34}$ The first two, he argued, developed earlier as responses to eighteen century thought, namely liberalism and individualism, while the radical and extreme right "were more developments of the nineteenth and early twentieth centuries; they sought specific response to the rise of socialist movements, in particular their more economic, end-state concerns. ${ }^{35}$ Thus the radical and extreme right understandably share certain similarities. In the case of the Baltic States, both EVL and Pèrkonkrusts were idealistic, somewhat irrational movements. They had a vision of nation as true community and did not focus on economic programmes, but sought the mass mobilisation on the national grounds cutting across the class structure of the society. Both movements were extremely critical of the left. However, the styles of thought and, I would add, the manner of their presentation varied a lot. In EATWELL's view, " $a$ defining characteristic of the extreme right is the paucity of its intellectual tradition. The reactionary, moderate and radical right have produced significant political theorists. The extreme right has tended more to produce propagandists, interested in telling people what to think rather than how to think, and lacking in originality." ${ }^{36}$ This description fits Thundercross perfectly. Further EATWELL referred to more features - anti-Semitism and drawing on the conspiracy theory - characteristic of the extreme right but not associated with the radical right. The above features were found with both the Dievturi and Pērkonkrusts.

Further, EVL and Pērkonkrusts had different perceptions of history, although the Past was crucial entity for both organisations. History is always of paramount importance for the nationalist movements. As Anthony SMITH has pointed out -

It is history, and history alone, which can furnish the bases of ethnic identity and the psychic reassurance of communal security that goes with it $[\ldots]$ it is not the amount of such history, or even its dramatic value, that is important; what nationalists require from their historical researches is the definition of an ethnic atmosphere, unique to that community, and the provision of moral qualities (and heroic embodiments) peculiar to the group. ${ }^{37}$

EVL referred mainly to the recent history. The members of the organisation shared a particular experience - participation in the War of Independence, which served as a point of departure for all their ideology and superiority claims. The War of Independence was still remembered by the Estonians in the thirties and probably that was exactly the reason why the Veterans chose to evoke it.

\footnotetext{
${ }^{34}$ EATWELL 1985: 63

${ }^{35}$ Ibid.

36 Ibid, p. 17.

${ }^{37}$ SMITH 1976: 8.
} 
Pérkonkrusts, in their turn, bet everything on what nobody could possibly remember, an absolutely unrealistic ideal - Latvia without minorities. For that purpose they needed a pattern that could be found nowhere in modern history and had to be sought in the times immemorial - in the invented image of the Latvia Felix and the distant glorious Indo-European past. BRASTIŅŠ's thus provided exactly what the Perkonkrusts' ideologues were missing. His anti-Christian zeal also favoured the myth of the unjust treatment of the Latvian nation through history as the Christianisation of Latvia in the 13th century coincided with the loss of political independence.

EVL needed nothing of this. Their discourse, in contrast, saw the deaths and suffering at the battlefields during the Independence War as purposeful acts. It also drew strongly upon the value of sacrifice. The Christian religion (in its Lutheran form, traditional to the country) was an understandable choice - the Veterans needed a religion that gives strength in suffering.

It seems that the extreme right politicians are more likely to make the choice of pre-Christian revivalism and the radical right would rather prefer the Protestant Christianity..$^{38}$ It is difficult to tell, how would the relationship of the religious and the political right ideologies develop, had Estonia been a predominantly Catholic country. The radical ideologies in some European countries, Spain and Austria being examples, had formed links with the Catholic Churches. ${ }^{39}$ However, it seems that the Protestant Churches are more prone to develop intellectual, and sometimes also institutional, ties with the right-wing politics. There are few reasons for that. In his analysis of the encounter of Christianity and what he calls three quasi religions (nationalism, socialism/communism and humanism) Paul TILLICH has pointed to the positive evaluation of the secular realm by Protestantism:

Protestantism is more open to and, consequently, a more easy pray of the quasi religions. The Roman Church has denied to all three types of quasi-religion all religious significance. Its positive evaluation of the secular makes the relationship of Protestantism to quasi-religion much more dialectical and even ambiguous. Protestantism can receive and transform the religious elements of the quasi-religions..., it has also partly - though never totally - succumbed to their radicalised forms. ${ }^{40}$

The Protestant Churches came into existence together with the application of the vernacular languages to the intellectual discourse (services held in the national languages, translations of the Bible, etc.). The importance of the national issues in general is greater in Protestant Churches than in the Catholic Church. Protestant

\footnotetext{
${ }^{38}$ I refer here to the European developments. There were, though, the right-wing political movements outside the Christian world - the Japanese fascism, for example. The discussion of those is, however, beyond my competence.

${ }^{39}$ See SMITH, D. 1970: 14-16.

40 Tillich 1961: 48-49.
} 
Churches are also in many cases structured along the national lines, especially in smaller countries. By definition, there can be no state Catholic Church in any country. This is another reason why the Protestant Churches are easier to penetrate for any ideas, but particularly the nationalist ones.

At the same time, we should not pass unnoticed that the pre-Christian revivalism movements in many countries during the inter-war period, and definitely in Latvia were formalised according to the Protestant pattern. This is one more reason to discriminate it from the present day neo-Paganism which is doctrinally more flexible and does not have an idea of the "one true creed". It was mentioned earlier that BRASTIN̦Š modelled his catechism on Luther's seminal text. This is not surprising as BRASTIN̦Š and all other leaders of the movement came from (nominal) Lutheran families. The hostility of the Dievturi was considerably greater towards the Lutheran Church and less extended to the Catholics - the fact which is, in itself, highly suggestive. The Lutheran theologians, in their turn, returned the animosity - several of them published articles against the Dievturiba. Cold as their relationship were, both groups understood what their opponents were talking about as they shared common terminology. At the same time there was almost no reference to the Dievturi movement in the Catholic press - the pre-Christian revivalists were not taken serious. The style of discourse applied by the pre-Christian revivalists was in itself very Protestant. They understood the Truth as something that had to be recovered and purified (through the study of the folklore texts, in the Latvian case), rather than created. Such an approach could only come into being in a culture that was shaped by the Protestant Church. I believe that the impact of the Reformation on the origins and development of the European nationalism - often seen as a victorious rival of the Church - had been far more greater than is immediately evident.

\section{LITERATURE}

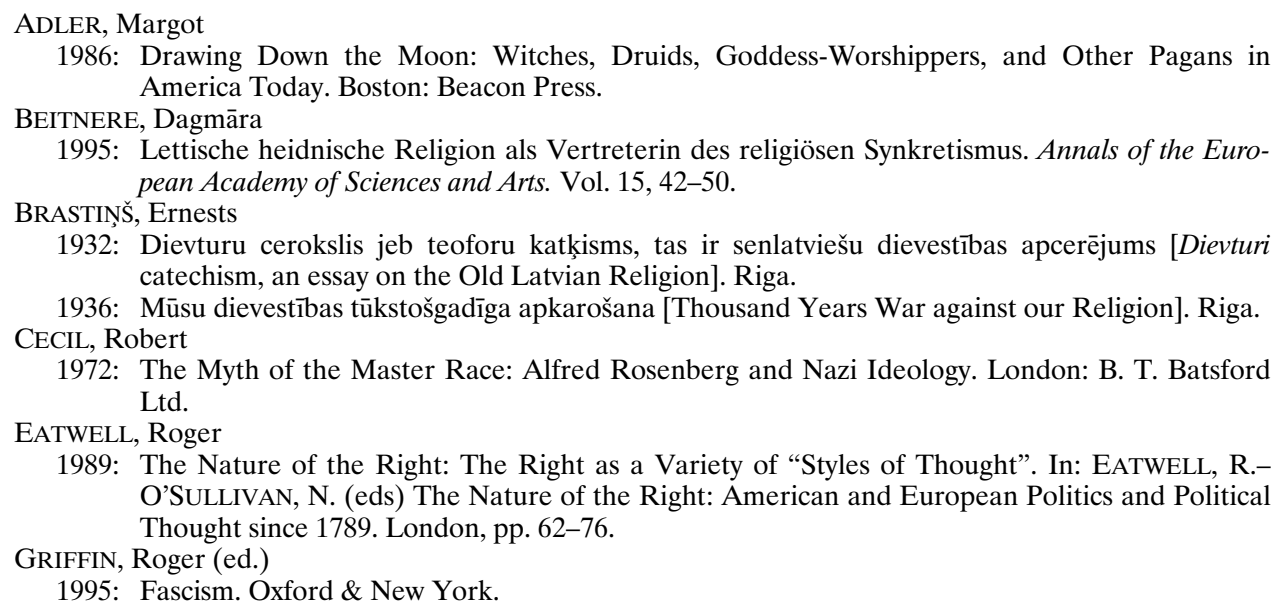


HOBSBAWM, Eric

1983: Introduction: Inventing Traditions. In: HoBSBAwM, E.-RANGER, T. (eds.) The Invention of Tradition. Cambridge.

KASEKAMP, Andres

1996: The Politics of Popular Initiative: The Radical Right in the Interwar Estonia. Theses submitted for the degree of Doctor of Philosophy. School of Slavonic and East European Studies, University of London.

1999: Radical Right-wing Movements in the North East Baltic. Journal of Contemporary History. Vol. 1. Nr. 4. pp. 587-600.

KRUMINA-KonKOVA, Solveiga-GILLS, Nikandrs

1998: Die Lebendigkeit von Religion und Kirche im gegenwärtigen Lettland. In: Religiöser Wandeln in den Postkommunistischen Ländern Ost- und Mitteleuropas. Eds. POLLAK, D., BOROWIK, I., JAGODZINSKI, W., Würzburg, S. 429-477.

MisĀNE, Agita- PrIEDİTE, Aija

1997: National Mythology in the History of Ideas in Latvia: A View from Religious Studies. In: Hosking, G.-SCHÖPfLIN, G., Myths and Nationhood. London.

MISIUNAS, Romuald J.

1970: Fascist Tendencies in Lithuania. Slavonic and East European Review 49, 88-109.

PAEGLIS, Armands

1994: "Pērkonkrusts" pār Latviju (1932-1944) [“Thundercross" over Latvia]. Rīga: Zvaigzne ABC.

PELKAUS, Elmārs

1992: Brastiņu Ernests padomju cietumā [Ernests Brastiņš in the Soviet prison]. Atmoda Atpûtai. 16.09.92. pp. 26-27.

PRIEDīTE, Aija

1998: National Identity and Cultural Identity: the History of Ideas in Latvian in the Nineteenth and Twentieth Centuries. In: BRANCH, M. (ed.), National History and Identity: Approaches to the Writing of National History in the North-East Baltic Region Nineteenth and Twentieth Centuries. Studia Fennica, Ethnologica, Vol. 6. Helsinki: Finnish Literature Society.

RAMOŠKAITE-SVERDOLIENE, Živile

1996: Archaic Folklore Elements in Contemporary Everyday Life. In: KõIVA, M. (ed). Contemporary Folklore: Changing World Views and Traditions. Tartu. pp. 79-85.

RAUN, Toivo

1991: Estonia and Estonians. Stanford.

SHNIRELMAN, Victor A.

1998a: Russian Neo-pagan Myths and Antisemitism. In: Analyses of Current Trends in Antisemitism. Acta No. 13.

http://sicsa.huji.ac.il/13schnirl.html, as on 10/08/99.

1998b: Heoiazichestvo i nacionalizm. Vostochnoevropeiskii areal. [Neo-paganism and Nationalism in Eastern Europe.] Rossiiskaia Akademia Nauk. Institut etnologii i antropologii. Isslegovaniia po prikladnoi i neotlozhhoi etnologii. Vol. 114. pp. 1-26.

SMITH, Anthony D.

1976: The Formation of Nationalists Movements. In: Idem (ed.) Nationalist Movements. London. pp. $1-30$.

SMITH, David

1970: Left and Right in Twentieth-Century Europe. London.

ŠILDE, Ādolfs

1988: Ardievas Rīgai [Farewell to Riga]. S. 1: Grāmatu Draugs.

STARK, Rodney-BAINBRIDGE, William Sims

1985: The Future of Religion: Secularization, Revival and Cult Formation. Berkeley e.a.: University of California Press.

TILLICH, Paul

1963: Christianity and the Encounter of the World Religions. New York: Columbia University Press.

VÄSTRIK, Ergo-Hart

1996: The Heathens in Tartu in 1987-1994: Heritage Protection Club Tõlet. In: KõIVA, M. (ed.) Contemporary Folklore: Changing Views and Traditions. Tartu. pp. 86-104. 